\title{
Physicochemical properties of Scamorza ewe milk cheese manufactured with different probiotic cultures
}

\author{
M. Albenzio, ${ }^{* 1}$ A. Santillo, ${ }^{*}$ M. Caroprese, ${ }^{*}$ D. Ruggieri, ${ }^{*}$ F. Napolitano, $†$ and A. Sevi ${ }^{*}$ \\ *Department of the Sciences of Agriculture, Food and Environment (SAFE), University of Foggia, Via Napoli, 25, 71100 Foggia, Italy \\ †Scuola di Scienze Agrarie, Forestali, Alimentari ed Ambientali, University of Basilicata, Via dell'Ateneo Lucano 10, 85100 Potenza, Italy
}

\begin{abstract}
The present study was undertaken to produce functional Scamorza cheese from Gentile di Puglia ewe milk by incorporating probiotic strains into the cheese matrix and to evaluate the physicochemical characteristics of Scamorza ewe milk cheese. Gentile di Puglia ewe bulk milk was used for Scamorza cheese production. Cheeses were denoted S-CO for control Scamorza cheese, S-BB for Scamorza cheese made using a mix of Bifidobacterium longum and Bifidobacterium lactis, and S-LA for Scamorza cheese made using Lactobacillus acidophilus as probiotic strain. Cheeses were analyzed at 1, 7, and $15 \mathrm{~d}$ of ripening. Probiotic cell recovery in cheese was $7.55 \pm 0.07 \log _{10} \mathrm{cfu} / \mathrm{g}$ and $9.09 \pm 0.04 \log _{10} \mathrm{cfu} / \mathrm{g}$ in S-LA and S-BB cheese, respectively; probiotic cheeses also displayed the highest levels of lactic microflora. Reverse-phase HPLC chromatograms of the water-soluble nitrogen fraction showed a more complex profile in $\mathrm{S}-\mathrm{BB}$, with distinctive peaks in the early-eluting zone. The matured Scamorza cheese containing the mix of $B$. longum and $B$. lactis was characterized by significantly higher levels of Gln, Ser, Arg, Ile, and Leu, whereas cheese containing $L b$. acidophilus was characterized by higher levels of Tyr and Met. Total FFA content was the highest in S-LA, intermediate in S-BB, and the lowest in $\mathrm{S}-\mathrm{CO}$ cheese; in particular, Scamorza cheese containing $L b$. acidophilus showed the highest level of vaccenic acid, oleic acid, and total conjugated linoleic acid. Probiotic bacteria survived through the technological phases of pasta filata cheese production, maintained their specific metabolic pathways, and conferred functional properties to Scamorza ewe milk cheese.
\end{abstract}

Key words: pasta filata ewe milk cheese, probiotic, proteolysis, lipolysis

Received October 2, 2012

Accepted February 6, 2013.

${ }^{1}$ Corresponding author: m.albenzio@unifg.it

\section{INTRODUCTION}

The breeding of dairy sheep is characteristic of marginal and less-favorable areas where typical dairy products have been developed according to local available resources. Ewe milk can be an ideal substitute for bovine milk for the higher level of main components and minerals than cow milk, for subjects suffering from cow milk allergy. Most of the interest in ewe milk is focused in cheese manufacturing, with distinct characteristics according to their geographical area of production. In the Mediterranean area, almost $60 \%$ of sheep are totally or partially milked and about $90 \%$ of the milk is transformed into good-quality products often recognized by the European Union as Protected Designation of Origin (i.e., Pecorino Romano, Pecorino Sardo, Canestrato Pugliese, Roquefort, Idiazabal, and Manchego; Scintu and Piredda, 2007).

Gentile di Puglia is an autochthonous ovine breed of Southern Italy, a multiple purpose breed giving wool, milk, and meat. For its high level of nutrients, Gentile di Puglia milk gives high cheese yield and is destined to typical cheese production as Pecorino cheese, characterized by a long ripening time (Santillo and Albenzio, 2008; Santillo et al., 2009).

Pasta filata cheese varieties are mainly produced from cow and buffalo milk; the principal phases of pasta filata cheese production are the acid development, rennet catalyzed coagulation, and heating and stretching of the curd mass. The process of heating and stretching results in the visible alignment of protein fibers within the curd, which entraps coalesced fat and moisture, giving a glossy, white appearance. Scamorza cheese is a pasta filata-type cheese whose name means to behead, reflecting the cutting of the pear-shaped cheese during molding. In Italy, the only referenced pasta filata cheese from raw sheep milk is Vastedda della Valle del Belice, recognized as Protected Designation of Origin by European Union no. 283/28.10.2010.

The supplementation of cheese with probiotic bacteria represents the aggregation of added value to a product that already has benefits inherent in its composition. In functional foods, the genera of Bifidobacterium and 
Lactobacillus are widely used as probiotic microorganisms, but also other bacteria, including the genus Enterococcus and yeasts, have been exploited (Sanders and Huis in't Veld, 1999). The development of probiotic cheese is a current topic in the scientific literature and represents a trend for the dairy industry (Albenzio and Santillo, 2013). Probiotics added to cheese yield a wide spectrum of enzymes able to influence the biochemical events involving protein and lipid fractions in cheese during ripening. These events have an effect on the development of texture, flavor, and health components of cheese.

For its composition, Gentile di Puglia ewe milk is suitable for cheesemaking. In this study, such ewe milk was tested to produce Scamorza ewe milk cheese with the aim to increase the market share of ewe milk cheese typology and to promote autochthonous breed farming. In particular, the present research aimed to (1) produce functional Scamorza ewe milk cheese from Gentile di Puglia ewe milk by incorporating probiotic strains into the cheese matrix and (2) evaluate the physicochemical characteristics of Scamorza ewe milk cheese.

\section{MATERIALS AND METHODS}

\section{Strains and Growth Condition}

Lyophilized cultures of Lactobacillus acidophilus (LA-5; Chr. Hansen SpA, Milan, Italy), or a mix (1:1) of Bifidobacterium longum (BL-46 DSM14583) and Bifidobacterium lactis (BB-12; Chr. Hansen) were grown for $48 \mathrm{~h}$ at $37^{\circ} \mathrm{C}$ in de Man, Rogosa, and Sharpe (MRS) broth (for Lb. acidophilus; Oxoid SpA, Milan, Italy) or in MRS + cysteine $(0.05 \%$; cMRS, cysteine; Sigma-Aldrich, Milan, Italy; for bifidobacteria). After reaching the stationary phase of growth, the probiotic strains were heated in a water bath at $65^{\circ} \mathrm{C}$ for $30 \mathrm{~min}$ to induce heat adaptation; 6 heat treatments were performed on each probiotic strain tested, adapted from the method described in Minervini et al. (2012). Cell cultures $(30 \mathrm{~mL})$ were centrifuged at $1,200 \times g$ for 10 $\mathrm{min}$; then, the supernatant was discarded and $30 \mathrm{~mL}$ of sterile distilled water added to the pellet. The harvested cells were plated on selective medium to test cell recovery after heat treatment; cell counts of $L b$. acidophilus and B. longum and B. lactis ranged between 8.5 and $9.0 \log \mathrm{cfu} / \mathrm{mL}$. Probiotic strains used in this study were previously tested for their tolerance in a simulated human gastrointestinal system (Bove et al., 2012).

\section{Analyses of Ewe Milk}

Bulk milk and whey samples collected after milk clotting and extraction of the curd were analyzed for fat, protein, and lactose content (MilkoScan FT 120; Foss Electric A/S, Hillerød, Denmark), pH value (GLP 21; Crison Instruments SA, Barcelona, Spain), and SCC (Fossomatic Minor; Foss Electric A/S). Total mesophilic bacteria were enumerated by using plate count agar (PCA; Oxoid, Milan, Italy) at $37^{\circ} \mathrm{C}$ for $24 \mathrm{~h}$.

\section{Scamorza Ewe Milk Cheese Production}

Three Scamorza cheesemaking trials were performed in triplicate in an industrial dairy plant according to the following procedure. Thermized ewe milk $\left(60^{\circ} \mathrm{C}\right.$ for $\left.8 \mathrm{~s}\right)$ was inoculated with $1 \%$ commercial starter (Lyofast ST044; Sacco, Como, Italy) and with $2 \%$ heat-adapted cells of $L b$. acidophilus and a mix of B. longum and $B$. lactis. The $\mathrm{pH}$ was monitored until it reached the value of 5.7 and then liquid rennet (Chr. Hansen SpA) was added to vat milk; curd was obtained in about $20 \mathrm{~min}$. Curd was cut into cubes of $2 \times 2 \mathrm{~cm}$ and kept under whey for about $30 \mathrm{~min}$ until it reached $\mathrm{pH}$ 4.9. This $\mathrm{pH}$ value was found to confer the optimum stretchability to the curd obtained from ovine milk: higher $\mathrm{pH}$ value gave tough curd that fractured during stretching, whereas lower $\mathrm{pH}$ led to soft curd that collapsed during stretching. Then curd was drained, stretched mechanically in hot water $\left(80^{\circ} \mathrm{C}\right)$, and molded to give a cheese weight of about $250 \mathrm{~g}$ in a pear-like shape. Scamorza ewe milk cheese was dipped in cold water to firm and salted in brine $(22 \% \mathrm{NaCl})$ for $2 \mathrm{~h}$. The cheese was ripened at 8 to $10^{\circ} \mathrm{C}$ and 70 to $80 \%$ relative humidity for 15 d. Cheeses were denoted S-CO for control Scamorza cheese, S-BB for Scamorza cheese made using a mix of B. longum and B. lactis, and S-LA for Scamorza cheese made using $L b$. acidophilus as probiotic strain. Cheeses were analyzed at 1,7 , and $15 \mathrm{~d}$ of ripening.

\section{Chemical Composition and Microbiology of Scamorza Ewe Milk Cheese}

The $\mathrm{pH}$ of cheeses were determined according to the International Dairy Federation standard (IDF 1989). Total nitrogen and noncasein nitrogen contents were determined as described by Gripon et al. (1975), and water-soluble $\mathrm{N}$ was measured as described by Stadhouders (1960).

An aliquot of $20 \mathrm{~g}$ of cheese (from the inner and outer part) were diluted with $180 \mathrm{~mL}$ of $0.9 \% \mathrm{NaCl}$ saline solution and homogenized; then, serial dilutions were carried out and plated onto the appropriate media, as follows:

1. mesophilic lactic acid bacteria on MRS agar + $0.17 \mathrm{~g} / \mathrm{L}$ of cycloheximide (Sigma-Aldrich), incubated under anaerobic conditions at $30^{\circ} \mathrm{C}$ for $4 \mathrm{~d}$; 
2. thermophilic lactic acid bacteria on MRS agar $+0.17 \mathrm{~g} / \mathrm{L}$ of cycloheximide, incubated under anaerobic conditions at $44^{\circ} \mathrm{C}$ for $4 \mathrm{~d}$;

3. mesophilic lactococci on M17 agar $+0.17 \mathrm{~g} / \mathrm{L}$ of cycloheximide, incubated under anaerobic conditions at $30^{\circ} \mathrm{C}$ for $4 \mathrm{~d}$;

4. thermophilic lactococci on M17 agar $+0.17 \mathrm{~g} / \mathrm{L}$ of cycloheximide, incubated under anaerobic conditions at $44^{\circ} \mathrm{C}$ for $4 \mathrm{~d}$;

5. Bifidobacterium on MRS agar $+0.5 \%$ cysteine (Sigma-Aldrich) and nalidixic acid, paromycin sulfate, neomycin sulfate, and lithium chloride (NPNL), as reported by Vinderola and Reinheimer (1999), incubated at $37^{\circ} \mathrm{C}$ for $4 \mathrm{~d}$ under anaerobic conditions; and

6. Lb. acidophilus, on MRS agar acidified to $\mathrm{pH}$ 5.0 and incubated at $37^{\circ} \mathrm{C}$ for 48 to $72 \mathrm{~h}$ under anaerobic conditions.

The identities of $L b$. acidophilus and bifidobacteria were confirmed through microscopic examination.

\section{Assessment of Proteolysis}

The $\mathrm{pH}$ 4.6-soluble and -insoluble fractions were obtained according to the methods of Kuchroo and Fox (1982). The nitrogen fractions were analyzed by ureaPAGE using Protean II xi vertical slab gel equipment (Bio-Rad Laboratories Ltd., Watford, UK) according to the procedure reported in Santillo et al. (2007).

The peptide profiles of the $\mathrm{pH}$ 4.6-soluble fractions were determined by reverse-phase HPLC (RP-HPLC) using the Agilent 1260 Infinity system (Agilent Technologies Inc., Santa Clara, CA). The column used was a Zorbax 300 SB-C18 column $(250 \mathrm{~mm} \times 4.6 \mathrm{~mm} \times 5$ $\mu \mathrm{m}$; Agilent Technologies Inc.). The mobile phase was water (solvent A) and acetonitrile (solvent B), both containing $0.1 \%$ trifluoroacetic acid, and the solvent flow rate was $1 \mathrm{~mL} / \mathrm{min}$. The eluate was monitored at $220 \mathrm{~nm}$; all solvents were of chromatography grade (J. T. Baker Inc., Phillipsburg, NJ).

Individual amino acids were analyzed in freeze-dried water-soluble extracts of the cheeses. Amino acids were precolumn derivatized with o-phthalaldehyde-3-mercaptopropionic acid reagent (PN 5061-3335, Agilent Technologies Inc.) and fluorenylmethyl chloroformate reagent (PN 5061-3337, Agilent Technologies Inc.). The derivatized free amino acids (FAA) were separated, identified, and quantified by RP-HPLC (Agilent 1260 Infinity, equipped with a binary pump G1312A, automatic sampler G1313A, degassing system, and column oven thermostatized at $40^{\circ} \mathrm{C}$ ) on a Zorbax Eclipse AAA column $(4.6 \times 150 \mathrm{~mm}, 3.5 \mu \mathrm{m}$ film thickness; Agilent
PN9634000-9029). The mobile phases were (A) $40 \mathrm{n} M$ $\mathrm{NaH}_{2} \mathrm{PO}_{4}\left(\mathrm{pH}\right.$ 7.8) and (B) acetonitrile:methanol: $\mathrm{H}_{2} \mathrm{O}$ (45:45:10, vol/vol/vol). Quantization was done using the area under each peak with the Agilent software ChemStation. Detection was performed on an Agilent diode-array detector G1315B and a fluorescence detector G1321A.

\section{Assessment of Lipolysis}

Volatile FFA in cheese were extracted with diethyl ether: hexane $(1: 1, \mathrm{vol} / \mathrm{vol})$, after grinding with sodium sulfate and addition of $2.5 \mathrm{M}$ sulfuric acid (Kim Ha and Lindsay, 1990). Free FA were isolated using an aminopropyl column as adsorbent; the desorption of the FFA was carried out with $2 \%$ formic acid in diethyl ether (de Jong and Badings, 1990). Analysis and identification of FFA were performed according to the methods of Santillo et al. (2009).

Total lipids from cheeses were extracted according to the method of de Jong and Badings (1990). Free FA derivatization was performed, according to the method of Morrison and Smith (1964). Free FA and conjugated linoleic acid (CLA) were separated on a capillary column (HP88; $100 \mathrm{~m} \times 0.25 \mathrm{~mm}$ i.d., $0.20-\mu \mathrm{m}$ film thickness; Agilent Technologies Inc.). The injector and flame ionization detector temperatures were $260^{\circ} \mathrm{C}$. The temperature was held at $100^{\circ} \mathrm{C}$ for $1 \mathrm{~min}$ and then increased to a final temperature $240^{\circ} \mathrm{C}\left(3.5^{\circ} \mathrm{C} / \mathrm{min}\right.$, held for $15 \mathrm{~min}$ ). The split ratio was 1:50 and helium was the carrier gas, with a pressure of $227.5 \mathrm{kPa}$. Pure CLA isomers were purchased as FA methyl esters from Matreya Inc. (Pleasant Gap, PA). All solvents were analytical grade from J. T. Baker Inc. Free FA in cheese were grouped into 3 classes: short-chain FFA (SCFFA; C4:0-C10:0), medium-chain FFA (C12:0-C16:0), and long-chain FFA (>C18:0). Saturated fatty acids, MUFA, and PUFA were also calculated. Atherogenic and thrombogenic indices were calculated according to Ulbricht and Southgate (1991).

\section{Statistical Analysis}

All the variables were tested for normal distribution using the Shapiro-Wilk test (Shapiro and Wilk, 1965). Data on SCC and mesophilic cell load in ewe bulk milk were transformed into logarithmic form to normalize their frequency distributions before performing statistical analysis. Data on composition, microbial cell loads, FAA, FFA in cheese at 1,7 , and $15 \mathrm{~d}$ were processed by ANOVA using the PROC GLM for repeated measures of SAS (SAS Institute, 2011). The model used was Equation 1: 


$$
\mathrm{y}_{\mathrm{ijk}}=\mu+\alpha_{\mathrm{i}}+\beta_{\mathrm{j}}+(\alpha \beta)_{\mathrm{ijk}}+\varepsilon_{\mathrm{ijk}},
$$

where $y_{\mathrm{ijk}}$ is the dependent variable, $\mu$ is the overall mean, $\alpha_{i}$ is the effect of probiotic ( $i$ is the level of probiotic effect $=1-3), \beta_{\mathrm{j}}$ is the effect of time of ripening of cheese $(\mathrm{j}$ is the level for time of ripening $=1-3$ ), $(\alpha \beta)_{\mathrm{ijk}}$ is the interaction of probiotic $\times$ time of ripening ( $\mathrm{k}$ is the level for the interaction of probiotic $\times$ time of ripening $=1-9$ ), and $\varepsilon_{\mathrm{ijk}}$ is the error.

Results are presented as the least squares means and the variability of the data is expressed as the standard error of the mean response throughout the whole trial. Significant differences were considered at $P<0.05$. When significant effects were found (at $P<0.05$ ), the Tukey test was used as a post-hoc test.

Principal component analysis was performed by PROC PRINCOMP of SAS to obtain a visual representation of FAA distribution in cheeses at 1 and $15 \mathrm{~d}$ of ripening. The most significant 2 principal components were analyzed using a factorial analysis.

\section{RESULTS AND DISCUSSION}

\section{Ewe Milk and Scamorza Cheese Composition}

Principal composition of Gentile di Puglia ewe milk used for Scamorza cheesemaking showed mean values $( \pm \mathrm{SEM})$ of $7.60 \pm 0.25 \%$ for fat, $5.92 \pm 0.26 \%$ for protein, $4.77 \pm 0.03 \%$ for lactose, and $4.74 \pm 0.10 \%$ for casein. Raw milk showed high hygienic quality in terms of SCC and total mesophilic bacteria, with mean values $( \pm \mathrm{SEM})$ of $2.84 \pm 0.13$ and $1.36 \pm 0.18 \log _{10} \mathrm{cfu} / \mathrm{mL}$, respectively. These levels are within the limits reported by European Economic Community (EEC) directive $92 / 46$.

The addition of fresh cells of probiotic bacteria in ewe milk before cheesemaking to obtain functional Scamorza ewe milk cheese was successful, as demonstrated by probiotic cell recovery in cheese. Lactobacillus acidophilus and the mix of the $B$. longum and $B$. lactis mean values on specific media were $7.55 \pm 0.07$ and $9.09 \pm 0.04 \log _{10} \mathrm{cfu} / \mathrm{g}$ in S-LA and S-BB cheese, respectively. Mean values of thermophilic lactobacilli and lactococci were $2.3 \pm 0.03$ and $2.1 \pm 0.02 \log _{10}$ $\mathrm{cfu} / \mathrm{g}$ in control cheese; no differences were found for the mentioned lactic microflora in S-BB and S-LA cheese and mean values were $4.3 \pm 0.03$ and $4.1 \pm 0.02$ $\log _{10} \mathrm{cfu} / \mathrm{g}$ for thermophilic lactobacilli and lactococci, respectively. Mean values of mesophilic lactobacilli and lactococci were about $3.3 \pm 0.03$ and $3.1 \pm 0.02 \log _{10}$ $\mathrm{cfu} / \mathrm{g}$, respectively, in control cheese; no differences were found for the mentioned lactic microflora in S-BB and S-LA cheese and mean values were $4.3 \pm 0.03$ and $3.1 \pm 0.02 \log _{10} \mathrm{cfu} / \mathrm{g}$ for mesophilic lactobacilli and lactococci, respectively. Changes in $\mathrm{pH}$ in Scamorza ewe milk cheese during ripening are reported in Figure 1. The $\mathrm{pH}$ values were always lower in cheeses containing the mix of B. longum and B. lactis and Lb. acidophilus due to the metabolic activity associated with probiotic cells and lactic microflora. The adaptation trials of probiotic cells to heat stress conditions before cheese manufacturing allowed the survival and viability of the probiotic bacteria to the technological phases of pasta filata cheese production. In fact, Scamorza ewe milk cheese without probiotic cells showed an increase in $\mathrm{pH}$ at $7 \mathrm{~d}$ due to the lower lactobacilli and lactococci cell loads in S-CO cheese.

The $\mathrm{pH}$ values of Scamorza ewe milk cheese were always lower than those found in Fior di Latte, a fresh pasta filata cheese made from cow milk (Minervini et al., 2012). Stretchability, which is a specific phase of Mozzarella cheese production, is influenced by $\mathrm{pH}$ and calcium content (Feeney et al., 2002). Solubilization of calcium during cheesemaking occurs as a function of $\mathrm{pH}$ reduction; a decrease in calcium content is associated with decrease in number of binding sites for casein particles and allows transformation of the curd into soft and stretchable texture cheese (Joshi et al., 2004). The higher casein content and the higher colloidal calcium phosphate in ewe milk than cow milk could be responsible for the lower $\mathrm{pH}$ needed to obtain a stretchable curd.

\section{Proteolytic Patterns of Scamorza Ewe Milk Cheese}

Changes in water-soluble $\mathrm{N}$ content in Scamorza ewe milk cheese during ripening is reported in Figure 2. This nitrogen fraction collects the products of protein degradation as small peptides and FAA and gives information on the degree of hydrolysis in the cheese matrix. As expected, no differences were found among cheeses at $1 \mathrm{~d}$, whereas at the subsequent sampling time, S-BB cheese showed the highest value as an outcome of the grater proteolysis potential associated with $B$. longum and $B$. lactis. The same strains tested on $60-\mathrm{d}$ ripened Pecorino cheese performed major proteolysis due to their proteolytic enzymes (Santillo et al., 2009; Albenzio et al., 2010).

The quantitative analysis of electrophoretograms of the $\mathrm{pH}$ 4.6-insoluble $\mathrm{N}$ fraction of Scamorza ewe milk cheese during ripening is reported in Table 1. The percentage reduction in total casein, from 1 to $15 \mathrm{~d}$, was about $30 \%$ in S-BB, $29 \%$ in S-LA, and $26 \%$ in $\mathrm{S}-\mathrm{CO}$ cheese; as expected, casein fractions underwent a progressive reduction during ripening, although their evolution followed different trends. The $\beta-\mathrm{CN}$ fraction was the highest in Scamorza ewe milk cheese containing probiotic strains; accordingly, $\beta$-CN degradation 


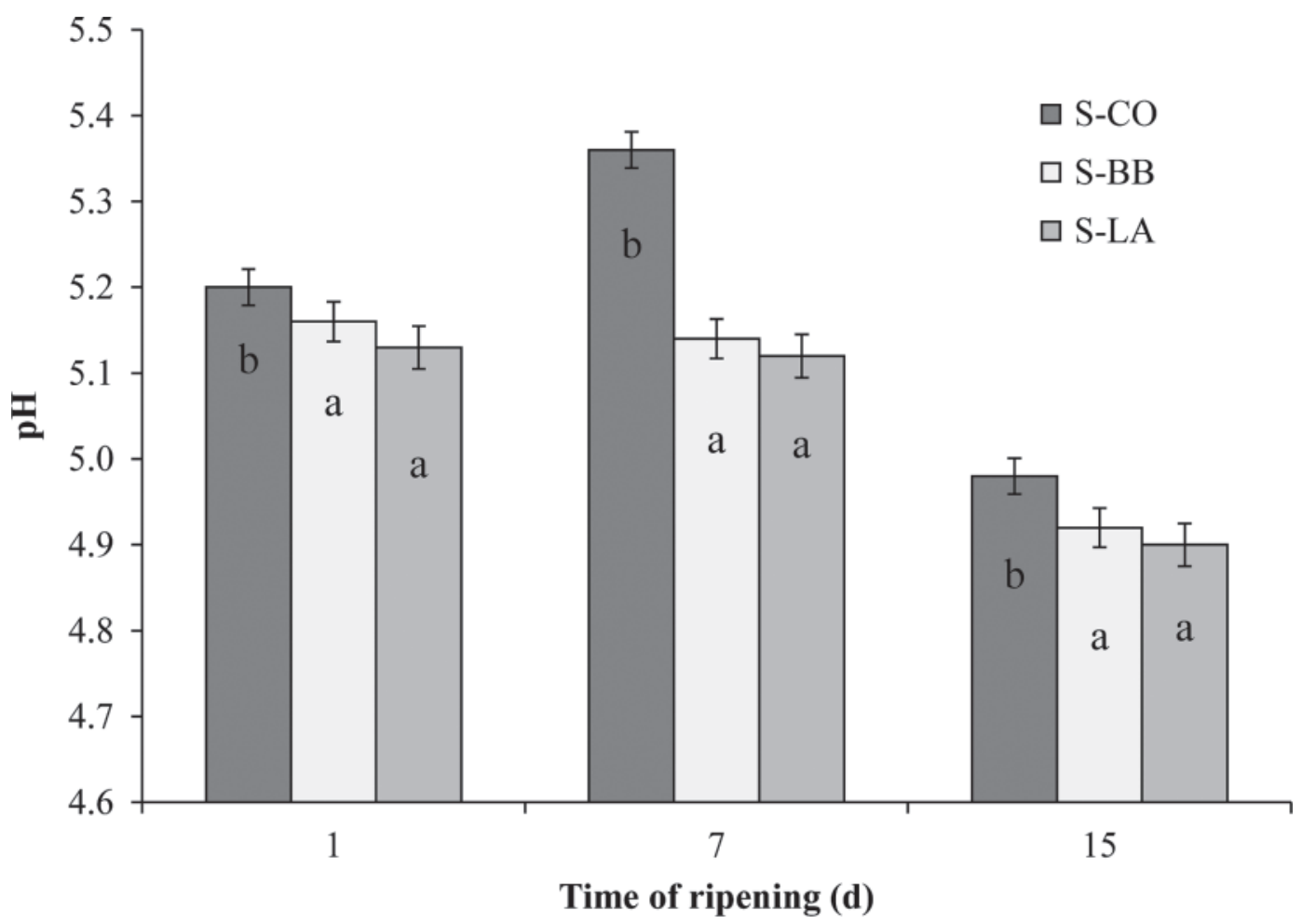

Figure 1. Changes in $\mathrm{pH}$ in Scamorza ewe milk cheese. S-CO = control Scamorza cheese; S-BB = Scamorza cheese containing the mix of Bifidobacterium longum and Bifidobacterium lactis; S-LA = Scamorza cheese containing Lactobacillus acidophilus. Error bars represent SEM; bars with different letters $(\mathrm{a}, \mathrm{b})$ differ $(P<0.05)$.

products ( $\gamma$-like components) were lower in S-BB and S-LA cheeses at $1 \mathrm{~d}$ of ripening but differences disappeared in the subsequent time of ripening, probably due to the further degradation of $\gamma$-like components to smaller peptides. The temperature of the stretching phase influences the residual rennet activity, microbial population, plasmin activity, and the rate that the curd is transformed into a molten mass; all of these factors affect the rate of proteolysis during cheese ripening (Rankin et al., 2006). In all cheeses at $1 \mathrm{~d}$, the great accumulation of $\gamma$-like components was ascribed to the action of plasmin, which is quite heat stable (Fox and Kelly, 2006) and may have survived the stretching phase at $80^{\circ} \mathrm{C}$. The $\alpha-\mathrm{CN}$ fraction underwent greater reduction in S-BB and S-LA than S-CO cheese, with a hydrolysis of more than $50 \%$ from 1 to $15 \mathrm{~d}$ of ripening. This difference was confirmed by the greater accumulation of $\alpha-\mathrm{CN}$ degradation products; this parameter was higher in S-BB, intermediate in S-LA, and lower in $\mathrm{S}-\mathrm{CO}$ cheese, confirming the ability of probiotic strains to promote proteolysis.

The RP-HPLC chromatograms of the water-soluble $\mathrm{N}$ fraction of Scamorza ewe milk cheese at $15 \mathrm{~d}$ of ripening are reported in Figure 3. The sum of the areas for the peaks detected in the chromatograms showed an almost 5-fold increase in S-BB cheese, 3-fold increase in S-LA cheese, and 2-fold increase in control cheese from 1 to 15 ripening days. The area ascribed to each zone showed an increase with time for S-BB and S-LA cheeses, whereas control cheese showed a reduction in the area of the peaks ascribed to zone II, and zone III did not change with ripening (data not shown). It has been reported that starter cultures are the main agent responsible for the formation of small peptides and amino acids (Feeney et al., 2002). In this trial, the major complexity of the chromatogram profile was due to the action of probiotic and lactic microflora on nitrogen molecules. In Pecorino cheese, the same probiotic strains tested in Scamorza ewe milk cheese showed broad enzymatic activity on different substrates, indicating the presence of different aminopeptidase and proline iminopeptidase (Santillo et al., 2012). In the area of the chromatograms with a retention time lower than $20 \mathrm{~min}, \mathrm{~S}-\mathrm{BB}$ cheese displayed 4 distinctive peaks (A, B, C, and D), whereas S-LA cheese showed a peak (indicated with an arrow in Figure 3) with a retention time of $11 \mathrm{~min}$ and $8 \mathrm{~s}$ and with an area of 6,337 arbitrary units. At the same retention time, S-CO cheese displayed a peak with an area of 1,673 arbitrary units, whereas the same peak was not detected in S-BB 
Table 1. Quantitative analysis of electrophoretograms of $\mathrm{pH}$ 4.6-insoluble $\mathrm{N}$ fraction of Scamorza ewe milk cheese

\begin{tabular}{|c|c|c|c|c|c|c|c|c|}
\hline $\begin{array}{l}\text { Protein } \\
\text { fraction }\end{array}$ & $\begin{array}{l}\text { Time of } \\
\text { ripening (d) }\end{array}$ & \multicolumn{3}{|c|}{ Scamorza cheese ${ }^{1}$} & SEM & \multicolumn{3}{|c|}{ Effect ( $P$-value $)$} \\
\hline$\gamma-\mathrm{CN}$ & 15 & 16.81 & 16.53 & 15.55 & 0.50 & * & NS & NS \\
\hline \multirow[t]{2}{*}{$\beta-\mathrm{CN}$} & 1 & $37.01^{\mathrm{a}}$ & $40.15^{\mathrm{b}}$ & $38.15^{\mathrm{b}}$ & & & & \\
\hline & 15 & $40.95^{\mathrm{a}}$ & $41.25^{\mathrm{b}}$ & $42.25^{\mathrm{b}}$ & 0.19 & $* *$ & $* * *$ & $* * *$ \\
\hline Degradation products & 15 & $14.43^{\mathrm{a}}$ & $19.17^{\mathrm{c}}$ & $15.63^{\mathrm{b}}$ & 0.21 & $* *$ & $* * *$ & $* * *$ \\
\hline
\end{tabular}

${ }^{a-c}$ Means within a row with different superscripts differ $(P<0.05)$.

${ }^{1} \mathrm{~S}-\mathrm{CO}=$ control Scamorza cheese; S-BB = Scamorza cheese containing the mix of Bifidobacterium longum and Bifidobacterium lactis; S-LA = Scamorza cheese containing Lactobacillus acidophilus.

${ }^{2} \mathrm{ND}=$ not detected.

$* P<0.05 ; * * P<0.01 ; * * * P<0.001$.

cheese. Late-eluting peaks showed a more complex profile together with higher peak areas than early-eluting peaks. In addition, a distinctive doublet peak named $\mathrm{E}$ was displayed only in the chromatogram of the soluble $\mathrm{N}$ extract from cheese made with the mix of $B$. longum and B. lactis. The distinctive peaks could include molecules deriving from protease specificity of probiotic bacteria and could contain trace molecules associated with the metabolism of $L b$. acidophilus and the mix of B. longum and B. lactis.

The study of FAA in cheese was performed to investigate the ability of probiotics to release amino acids. Principal component analysis of FAA of Scamorza ewe milk cheese at 1 and $15 \mathrm{~d}$ of ripening is reported in Figure 4; the first 2 principal components accounted for $87 \%$ of the total variance. The main factors explained by

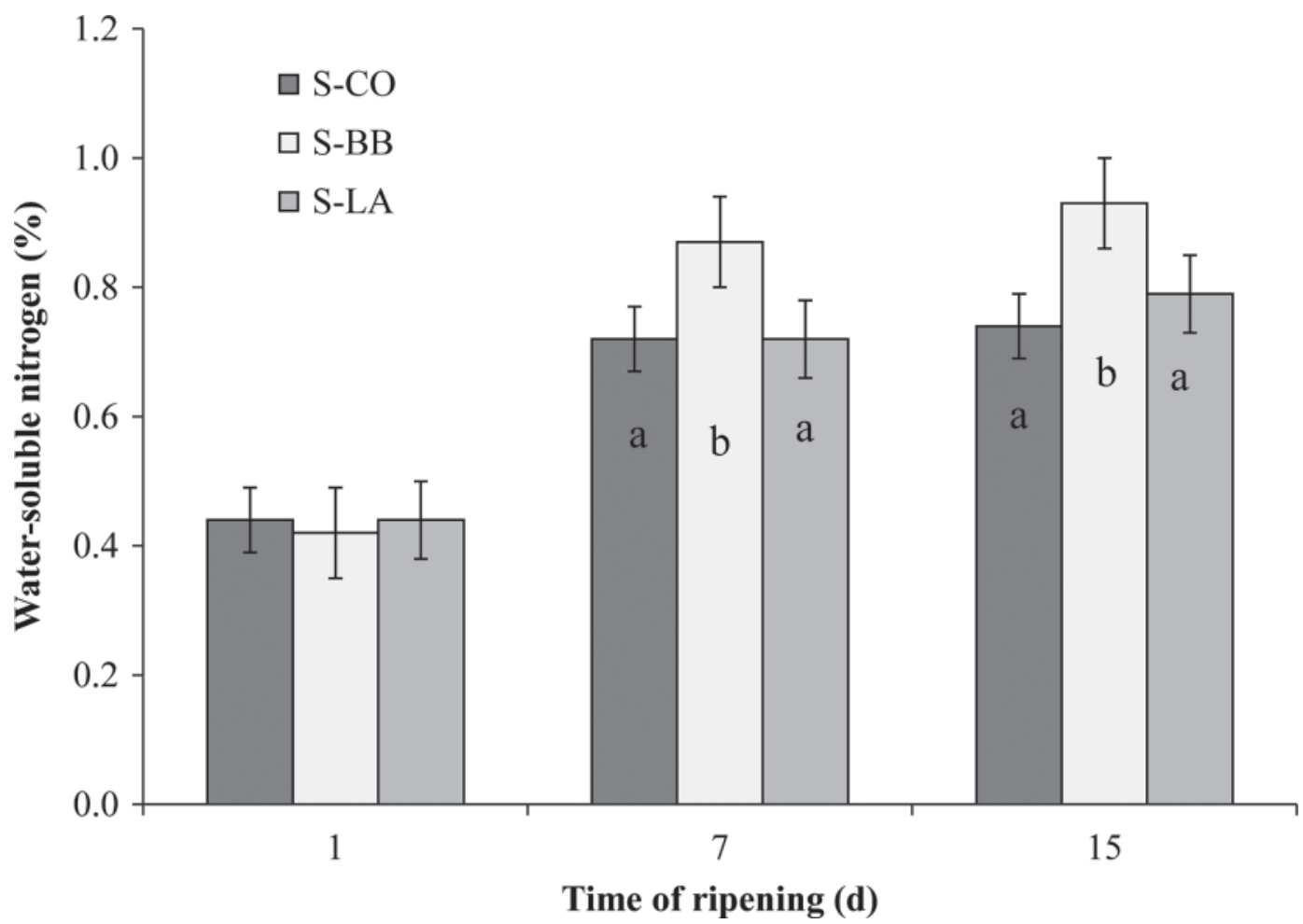

Figure 2. Changes in the water-soluble nitrogen fraction in Scamorza ewe milk cheese. S-CO = control Scamorza cheese; S-BB = Scamorza cheese containing the mix of Bifidobacterium longum and Bifidobacterium lactis; S-LA = Scamorza cheese containing Lactobacillus acidophilus. Error bars represent SEM; bars with different letters $(\mathrm{a}, \mathrm{b})$ differ $(P<0.05)$. 


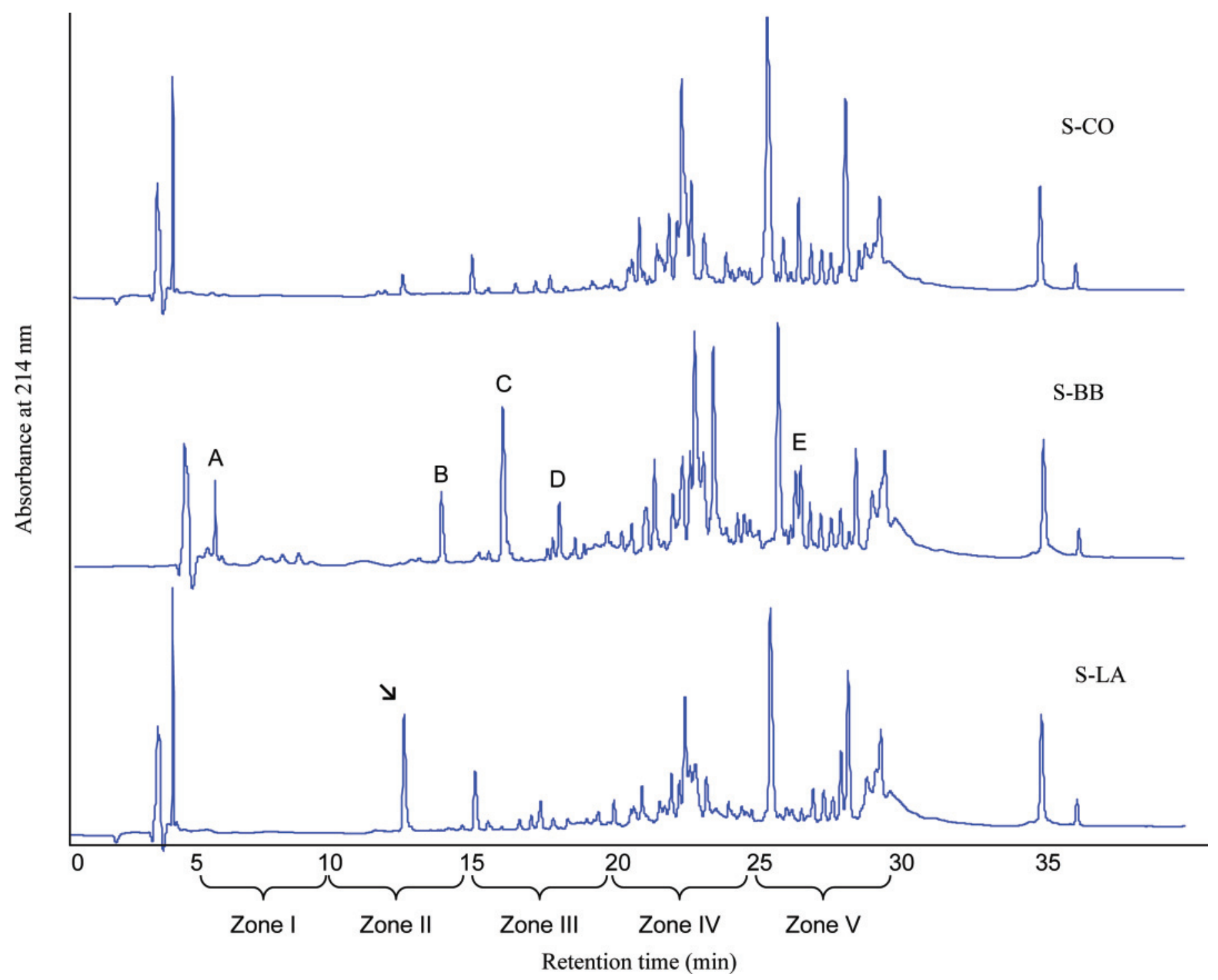

Figure 3. Reverse-phase HPLC of the water-soluble nitrogen fraction of Scamorza ewe milk cheese. S-CO = control Scamorza cheese; S-BB $=$ Scamorza cheese containing the mix of Bifidobacterium longum and Bifidobacterium lactis; S-LA = Scamorza cheese containing Lactobacillus acidophilus. A, B, C, D, E indicate distinctive peaks found in S-BB profile; the arrow indicates a distinctive peak in S-LA profile with a retention time of $11 \mathrm{~min}$ and $8 \mathrm{~s}$. Color version available in the online PDF.

the first principal component were Asp, Gln, Ser, Thr, Arg, Ala, Tyr, and Met, whereas His, Gly, Phe, and Lys were the dominating factors along the second principal component. Scamorza cheese containing probiotic strains moved along the first principal component as an outcome of the enrichment in the correlated FAA with advancing ripening. The matured Scamorza ewe milk cheese containing the mix of B. longum and B. lactis was characterized by significantly higher levels of Gln, Ser, Arg, Ile, and Leu, whereas cheese containing $L b$. acidophilus was characterized by higher levels of Tyr and Met. To the contrary, cheeses without probiotic strains moved along the second principal component due to the enrichment in Gly and Lys. In probiotic Cheddar cheese containing B. lactis, Leu and Gln were the most abundant FAA and were more abundant than in the control cheese (McBrearty et al., 2001).

\section{Lipolytic Patterns of Scamorza Ewe Milk Cheese}

Although lipolysis is a biochemical event most relevant in long-ripened cheeses, the study of FFA was performed to evaluate the effect of probiotic metabolism on the lipolytic pattern of Scamorza cheese. Fatty acid composition and atherogenic and thrombogenic indexes of Scamorza ewe milk cheese at $15 \mathrm{~d}$ of ripening 


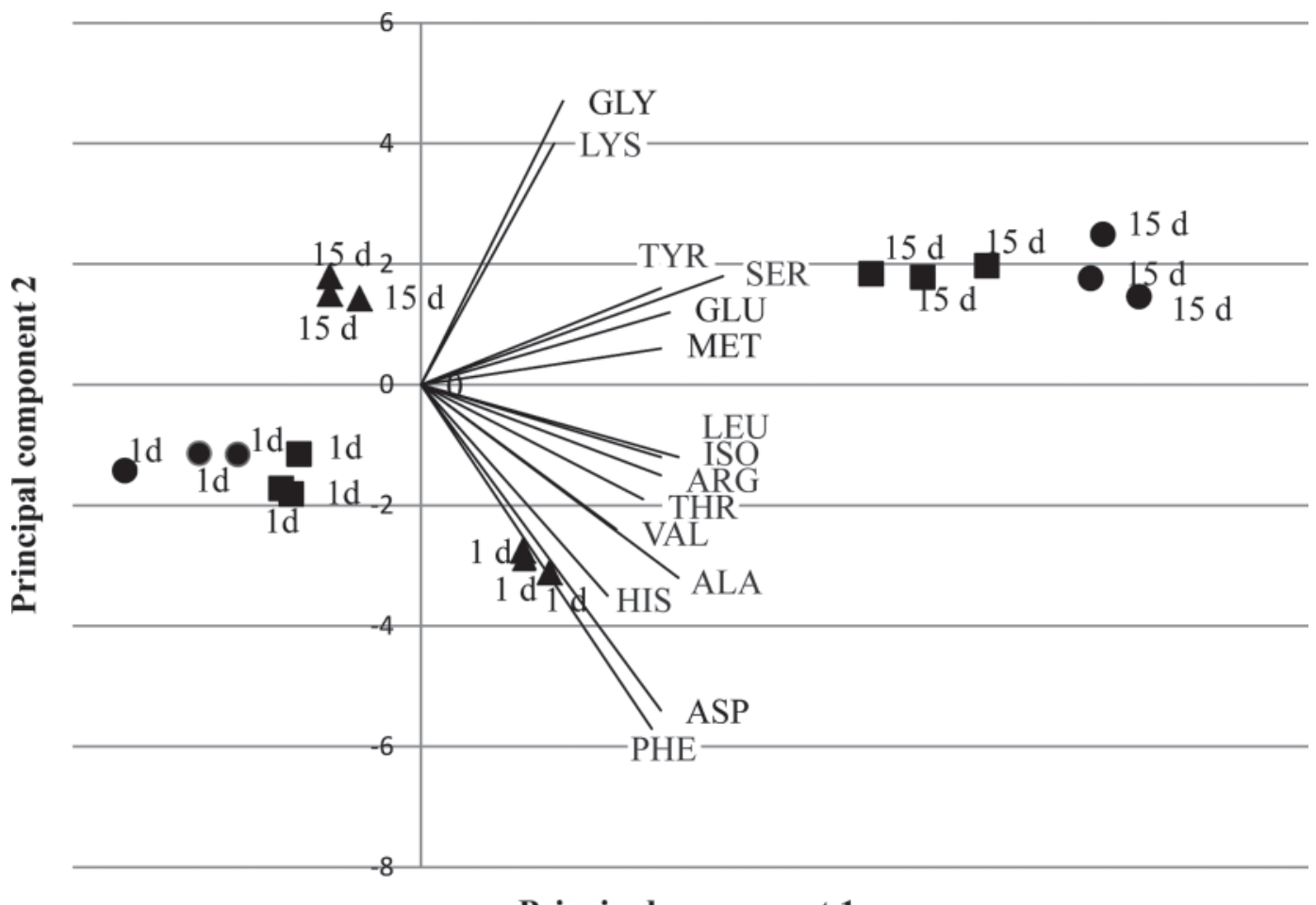

Principal component 1

Figure 4. Principal component analysis of free amino acids of Scamorza ewe milk cheese. $\boldsymbol{\Delta}=$ control Scamorza cheese $(\mathrm{S}-\mathrm{CO})$; $\boldsymbol{\square}=$ Scamorza cheese containing the mix of Bifidobacterium longum and Bifidobacterium lactis (S-BB); $\bullet$ Scamorza cheese containing Lactobacillus acidophilus (S-LA).

are reported in Table 2. The content of SCFFA was the highest in S-BB, intermediate in S-LA, and the lowest in $\mathrm{S}-\mathrm{CO}$ cheese, whereas the content of medium-chain FFA and long-chain FFA was the highest in S-LA cheese. The greater abundance of the free forms of SCFFA in cheeses containing probiotic could be attributed to the lipases associated with lactic acid microflora, which are specific for short-chain FA (de la Fuente et al., 1993). Furthermore, short-chain FA are acknowledged as beneficial to human health because they are prevention agents against atherosclerosis, diabetes, obesity, and some types of carcinoma (Pariza et al., 2001). According to the degree of unsaturation, FFA were also clustered in SFA, MUFA, and PUFA, which showed the highest levels in S-LA, intermediate in S-BB, and the lowest in S-CO cheese. Scamorza cheese containing $L b$. acidophilus showed the highest level of vaccenic acid, oleic acid, and total CLA. Furthermore, in S-LA cheese, the cis-9,trans-11 CLA isomer was the most abundant, being about $70 \%$ of the total CLA isomers. The evolution of vaccenic acid, linolenic acid, and the cis-9,trans 11 CLA isomer of Scamorza ewe milk cheese from ewe milk during ripening is shown in Figure 5.

Sheep cheese is a natural source of beneficial FA in human health; indeed, the highest CLA concentration in ovine cheeses compared with goat and cow cheeses is widely reported in the literature (Cruz-Hernandez et al., 2006). Similar to nutraceuticals, CLA are potentially important in alleviating major diseases such as cancer, atherosclerosis, and diabetes in humans (Benjamin and Spener, 2009). Among many other factors, diet is the most significant factor affecting milk CLA content, with increasing levels due to the increasing proportion of pasture in the diet (Collomb et al., 2006). Furthermore, in ewes, diet supplementation with sunflower (Hervás et al., 2008) or linseed oils (Gómez-Cortés et al., 2009) substantially improves the content of CLA and other healthy FA in milk. Previous research showed the capability of $L b$. acidophilus to increase the level of CLA in Pecorino cheese (Santillo et al., 2009). Furthermore, factors involved in the cheesemaking process, such as heat treatment of milk or curd (or both), addition of starter cultures, and ripening, generally do not affect the CLA content in milk fat (Prandini et al., 2011). In the current study, CLA content in pasta filata cheese from ovine milk containing Lb. acidophilus confirmed the capability of this strain to survive the stressful stretching conditions and also revealed the ability of $L b$. acidophilus to maintain its specific metabolic pathways. 
Table 2. Least squares means of FFA composition ( $\mathrm{mg} / \mathrm{g}$ of cheese), and atherogenic and thrombogenic indices of Scamorza ewe milk cheese

\begin{tabular}{lccccc}
\hline & \multicolumn{3}{c}{ Scamorza cheese } & & \multirow{2}{*}{ Effect (P-value) } \\
\cline { 2 - 3 } \cline { 5 - 6 } FFA $^{1}$ & S-CO & S-BB & S-LA & SEM & Probiotic \\
\hline Short-chain FA & $3.50^{\mathrm{a}}$ & $5.52^{\mathrm{c}}$ & $4.49^{\mathrm{b}}$ & 0.11 & $* *$ \\
Butyric acid (C4:0) & $0.89^{\mathrm{a}}$ & $1.35^{\mathrm{c}}$ & $1.04^{\mathrm{b}}$ & 0.03 & $*$ \\
Capric acid (C10:0) & $1.50^{\mathrm{a}}$ & $2.34^{\mathrm{c}}$ & $2.03^{\mathrm{b}}$ & 0.01 & $* *$ \\
Medium-chain FA & $11.48^{\mathrm{a}}$ & $13.50^{\mathrm{b}}$ & $16.64^{\mathrm{c}}$ & 0.45 & $* *$ \\
Myristic acid (C14:0) & $2.08^{\mathrm{a}}$ & $3.51^{\mathrm{b}}$ & $3.99^{\mathrm{c}}$ & 0.14 & $* *$ \\
Palmitic acid (C16:0) & $6.69^{\mathrm{a}}$ & $7.49^{\mathrm{a}}$ & $9.81^{\mathrm{b}}$ & 0.65 & $*$ \\
Long-chain FA & $11.68^{\mathrm{a}}$ & $13.19^{\mathrm{b}}$ & $18.32^{\mathrm{c}}$ & 0.48 & $* *$ \\
SFA & $17.77^{\mathrm{a}}$ & $21.80^{\mathrm{b}}$ & $25.70^{\mathrm{c}}$ & 0.65 & $* *$ \\
MUFA & $7.24^{\mathrm{a}}$ & $8.24^{\mathrm{b}}$ & $11.27^{\mathrm{c}}$ & 0.10 & $* *$ \\
Vaccenic acid (trans-11 C18:1) & $0.43^{\mathrm{a}}$ & $0.67^{\mathrm{a}}$ & $1.01^{\mathrm{b}}$ & 0.06 & $* * *$ \\
Oleic acid (cis-9 C18:1) & $5.93^{\mathrm{a}}$ & $6.67^{\mathrm{a}}$ & $8.92^{\mathrm{b}}$ & 0.32 & $* *$ \\
PUFA & $1.95^{\mathrm{a}}$ & $2.38^{\mathrm{b}}$ & $2.78^{\mathrm{c}}$ & 0.11 & $*$ \\
Total CLA & $0.19^{\mathrm{a}}$ & $0.22^{\mathrm{b}}$ & $0.31^{\mathrm{c}}$ & 0.05 & $* *$ \\
cis-9,trans-11 CLA & $0.14^{\mathrm{a}}$ & $0.16^{\mathrm{b}}$ & $0.22^{\mathrm{b}}$ & 0.06 & $* *$ \\
n-3 & $0.71^{\mathrm{a}}$ & $0.95^{\mathrm{b}}$ & $1.04^{\mathrm{b}}$ & 0.07 & $*$ \\
Linolenic acid (C18:3n-3) & $0.56^{\mathrm{a}}$ & $0.69^{\mathrm{b}}$ & $0.81^{\mathrm{c}}$ & 0.03 & $* * *$ \\
EPA (C20:5n-3) & 0.04 & 0.07 & 0.07 & 0.01 & NS \\
DHA (C22:6n-3) & 0.02 & 0.05 & 0.03 & 0.01 & NS \\
AI & $2.09^{\mathrm{b}}$ & $1.89^{\mathrm{a}}$ & $1.97^{\mathrm{a}}$ & 0.01 & $* *$ \\
TI & $2.02^{\mathrm{b}}$ & $1.87^{\mathrm{a}}$ & $1.95^{\mathrm{a}}$ & 0.02 & $*$ \\
\hline
\end{tabular}

${ }^{\mathrm{a}-\mathrm{c}}$ Means within a row with different superscripts differ $(P<0.05)$.

${ }^{1} \mathrm{CLA}=$ conjugated linoleic acid; $\mathrm{n}-3=\Sigma$ PUFA n-3 series; EPA = eicosapentaenoic acid; DHA = docosahexaenoic acid; $\mathrm{AI}=$ atherogenic index $=(\mathrm{C} 12: 0+4 \times \mathrm{C} 14: 0+\mathrm{C} 16: 0) /[\Sigma \mathrm{MUFA}+\Sigma \mathrm{PUFA}(\mathrm{n}-6)$ and $(\mathrm{n}-$ $3)] ; \mathrm{TI}=$ thrombogenic index $=(\mathrm{C} 14: 0+\mathrm{C} 16: 0+\mathrm{C} 18: 0) /[0.5 \times \Sigma$ MUFA $+0.5 \times \Sigma$ PUFA $(\mathrm{n}-6)+3 \times \Sigma$ $\operatorname{PUFA}(\mathrm{n}-3)+(\mathrm{n}-3) /(\mathrm{n}-6)]$.

${ }^{2} \mathrm{~S}-\mathrm{CO}=$ control Scamorza cheese; $\mathrm{S}-\mathrm{BB}=$ Scamorza cheese containing the mix of Bifidobacterium longum and Bifidobacterium lactis; S-LA = Scamorza cheese containing Lactobacillus acidophilus.

${ }^{*} P<0.05 ;{ }^{* *} P<0.01 ;{ }^{* * *} P<0.001$.

Although no differences were found among Scamorza ewe milk cheese, data on eicosapentaenoic acid and docosahexaenoic acid were reported to underline the nutritional value of Scamorza cheese from ewe milk. Eicosapentaenoic acid and docosahexaenoic acid are the most important n-3 FA that demonstrated beneficial effects on platelet aggregation and blood clotting, fasting, and postprandial triglyceride levels and on immune function and inflammatory response (Williams, 2000). The n-3 FA series were more abundant $(P>$ $0.05)$ in Scamorza cheese containing probiotics than in control cheese; in particular, probiotic bacteria addition positively influenced the linolenic acid n-3 content of Scamorza ewe milk cheese, which represents the main FA of the n-3 series. It is well known that cheese fat contains also other acids, such as myristic (C14:0) and palmitic (C16:0), which have negative implications for human health (Parodi, 2006). According to the equation proposed by Ulbricht and Southgate (1991), all unsaturated FA are considered to be equally effective in decreasing the risk for atherogenicity and thrombogenicity. The atherogenic and thrombogenic indices were lower in S-BB and S-LA than in S-CO, showing that Scamorza cheese containing probiotic strains may exert a beneficial effect on human health on the basis of its
FA profile. In general, atherogenic and thrombogenic indices found in all Scamorza ewe milk cheese were comparable with those reported for Pecorino cheese ripened at $60 \mathrm{~d}$ obtained from ewe milk improved for FA profile through the use of dietary supplements in dairy ewe feeding (Branciari et al., 2012).

\section{CONCLUSIONS}

The addition of probiotic strains ( $L b$. acidophilus and a mix of B. longum and B. lactis) to cheese milk sustained the production of probiotic Scamorza ewe milk cheese. Furthermore, the maturing process in cheeses was influenced differently according to the probiotic strain used. The mix of B. longum and B. lactis strains sustained greater proteolysis in cheese, leading to more complex soluble peptide and FAA profiles; The $L b$. acidophilus strain ruled lipolysis and was able to significantly increase vaccenic and oleic acids and CLA content in cheese. Considering that pasta filata-type cheese represents one of the largest manufactured cheese segments, the market of ovine dairy products could expand options in the pasta filata cheese category; the use of probiotic strains can improve the healthful features of this cheese. 

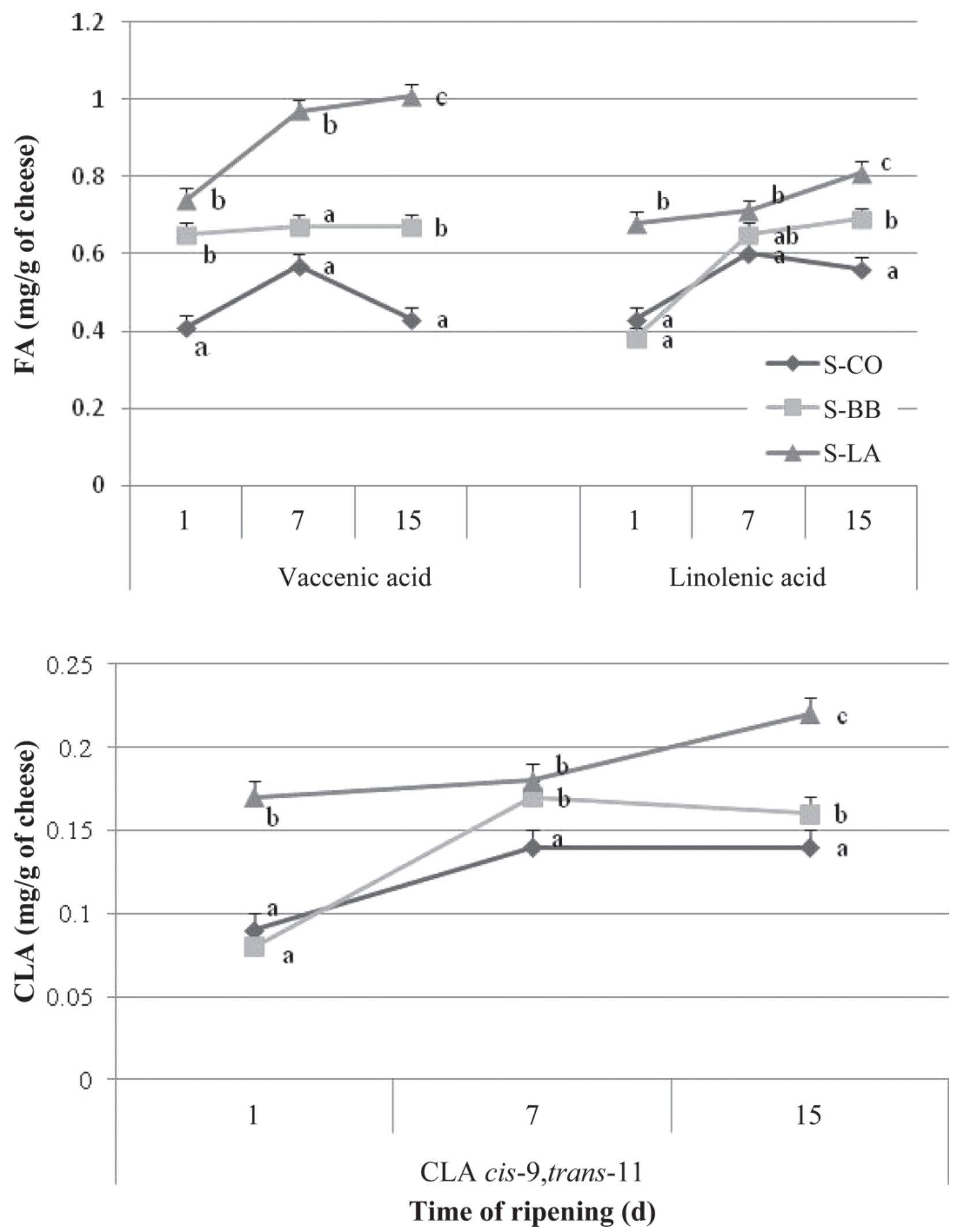

Figure 5. Changes in vaccenic acid, linolenic acid, and cis-9,trans-11 conjugated linoleic acid (CLA) isomer of Scamorza ewe milk cheese during ripening. $\mathrm{S}-\mathrm{CO}=$ control Scamorza cheese; $\mathrm{S}-\mathrm{BB}=$ Scamorza cheese containing the mix of Bifidobacterium longum and Bifidobacterium lactis; S-LA = Scamorza cheese containing Lactobacillus acidophilus. Error bars represent SEM; bars with different letters $(\mathrm{a}, \mathrm{b}, \mathrm{c})$ differ $(P<0.05)$. 


\section{ACKNOWLEDGMENTS}

The present work is part of the Research Program titled "Innovative strategies for quality and safety in ovine production," financially supported by the Italian Ministry of Agricultural, Food and Forestry Policies (MIPAAF, Rome, Italy).

\section{REFERENCES}

Albenzio, M., and A. Santillo. 2013. Ovine cheese: Production, consumption and role in human health. In Handbook of Cheese in Health. Wageningen Academic Publishers, Wageningen, the Netherlands.

Albenzio, M., A. Santillo, M. Caroprese, R. Marino, A. Trani, and M. Faccia. 2010. Biochemical patterns in ovine cheese: Influence of probiotic strains. J. Dairy Sci. 93:3487-3496.

Benjamin, S., and F. Spener. 2009. Conjugated linoleic acid as functional food: An insight into their health benefits. Nutr. Metab. $6: 36$.

Bove, P., A. Gallone, P. Russo, V. Capozzi, M. Albenzio, G. Spano, and D. Fiocco. 2012. Probiotic features of Lactobacillus plantarum mutant strains. Appl. Microbiol. Biotechnol. 96:431-441.

Branciari, R., A. Valiani, M. Trabalza-Marinucci, D. Miraglia, D. Ranucci, G. Acuti, S. Esposto, and L. Mughetti. 2012. Consumer acceptability of ovine cheese from ewes feed extruded linseed-enriched diets. Small Rumin. Res. 106(Suppl.):S43-S48.

Collomb, M., A. Schmid, R. Sieber, D. Wechsler, and E.-L. Ryhänen. 2006. Conjugated linoleic acids in milk fat: Variation and physiological effects. Int. Dairy J. 16:1347-1361.

Cruz-Hernandez, C., J. K. G. Kramer, J. Kraft, V. Santercole, M. M. Or-Rashid, Z. Deng, M. E. R. Dugan, and P. Delmonte. 2006. Systematic analysis of trans and conjugated linoleic acids in the milk and meat of ruminants. Pages 45-93 in Advances in Conjugated Linoleic Acid Research, Volume 3. M. P. Yurawecz, J. K. G. Kramer, O. Gudmundsen, M. W. Pariza, and S. Banni, ed. AOCS Press, Champaign, IL.

de Jong, C., and H. T. Badings. 1990. Determination of free fatty acids in milk and cheese. Procedures of extraction, clean up, and capillary gas chromatographic analysis. J. High Resol. Chromatogr. 13:94-98.

de la Fuente, M. A., J. Fontecha, and M. Juárez. 1993. Fatty acid composition of the triglyceride and free fatty acid fractions in different cows-, ewe- and goats-milk cheeses. Z. Lebensm. Unters. Forsch. 196:155-158.

Feeney, E. P., T. P. Guinee, and P. F. Fox. 2002. Effect of pH and calcium concentration on proteolysis in Mozzarella cheese. J. Dairy Sci. 85:1646-1654.

Fox, P. F., and A. L. Kelly. 2006. Indigenous enzymes in milk: Overview and historical aspects - Part I. Int. Dairy J. 16:500-516.

Gómez-Cortés, P., A. Bach, P. Luna, M. Juárez, and M. A. de la Fuente. 2009. Effects of extruded linseed supplementation on n-3 fatty acids and conjugated linoleic acid in milk and cheese from ewes. J. Dairy Sci. 92:4122-4134.

Gripon, J. C., M. J. Desmazeaud, D. Le Bars, and J. L. Bergere. 1975. Etude du rôle des micro-organismes et des enzymes au cours de la maturation des fromages. II.--Influence de la présure commercial. Lait 548:502-515.

Hervás, G., P. Luna, Á. R. Mantecón, N. Castañares, M. A. de la Fuente, M. Juárez, and P. Frutos. 2008. Effect of diet supplementation with sunflower oil on milk production, fatty acid profile and ruminal fermentation in lactating dairy ewes. J. Dairy Res. 75:399-405.

IDF (International Dairy Federation). 1989. Determination of pH. IDF Standard No 115A. FIL-IDF, Brussels, Belgium.
Joshi, N. S., K. Muthukumarappan, and R. I. Dave. 2004. Effect of calcium on microstructure and meltability of part skim Mozzarella cheese. J. Dairy Sci. 87:1975-1985.

Kim Ha, J., and R. C. Lindsay. 1990. Method for the quantitative analysis of volatile free and total branched-chain fatty acids in cheese and milk fat. J. Dairy Sci. 73:1988-1999.

Kuchroo, C. N., and P. F. Fox. 1982. Soluble nitrogen in Cheddar cheese: Comparison of extraction procedures. Milchwissenschaft $37: 331-335$.

McBrearty, S., R. P. Ross, G. F. Fitzgerald, J. K. Collins, J. M. Wallace, and C. Stanton. 2001. Influence of two commercially available bifidobacteria cultures on Cheddar cheese quality. Int. Dairy J. 11:599-610.

Minervini, F., S. Siragusa, M. Faccia, F. Dal Bello, M. Gobbetti, and M. De Angelis. 2012. Manufacture of Fior di Latte cheese by incorporation of probiotic lactobacilli. J. Dairy Sci. 95:508-520.

Morrison, W. R., and L. M. Smith. 1964. Preparation of fatty acids methyl esters and dimethylacetals from lipids with boron fluoridemethanol. J. Lipid Res. 5:600-608.

Pariza, M. W., Y. Park, and M. E. Cook. 2001. The biologically active isomers of conjugated linoleic acid. Prog. Lipid Res. 40:283-298.

Parodi, P. W. 2006. Nutritional significance of milk lipids. Pages 601639 in Advanced Dairy Chemistry: Volume 2: Lipids. 3rd ed. P. F. Fox and P. L. H. McSweeney, ed. Springer, New York, NY.

Prandini, A., S. Sigolo, and G. Piva. 2011. A comparative study of fatty acid composition and CLA concentration in commercial cheese. J. Food Compost. Anal. 24:55-61.

Rankin, A., C. M. Chen, D. Sommer, and D. Sommer. 2006. Mozzarella and Scamorza cheese. Chapter 150 in Handbook of Food Science, Technology, and Engineering. Vol. 4. Y. H. Hui, ed. CRC Press, Taylor \& Francis Group, Boca Raton, FL.

Sanders, M. E., and J. Huis in't Veld. 1999. Bringing a probioticcontaining functional food to the market: Microbiological, product, regulatory and labeling issues. Antonie van Leeuwenhoek 76:293-315.

Santillo, A., and M. Albenzio. 2008. Influence of lamb rennet paste containing probiotic on proteolysis and rheological properties of Pecorino cheese. J. Dairy Sci. 91:1733-1742.

Santillo, A., M. Albenzio, A. Bevilacqua, M. R. Corbo, and A. Sevi. 2012. Encapsulation of probiotic bacteria in lamb rennet paste: Effects on the quality of Pecorino cheese. J. Dairy Sci. 95:34893500 .

Santillo, A., M. Albenzio, M. Quinto, M. Caroprese, R. Marino, and A. Sevi. 2009. Probiotic in lamb rennet paste enhances rennet lipolytic activity, and CLA and linoleic acid content in Pecorino cheese. J. Dairy Sci. 92:1330-1337.

Santillo, A., M. Caroprese, R. Marino, A. Muscio, A. Sevi, and M. Albenzio. 2007. Influence of lamb rennet paste on composition and proteolysis during ripening of Pecorino Foggiano cheese. Int. Dairy J. 17:535-546.

SAS Institute. 2011. SAS/STAT User's Guide. Version 9.2. SAS Inst. Inc., Cary, NC.

Scintu, M. F., and G. Piredda. 2007. Typicity and biodiversity of goat and sheep milk products. Small Rumin. Res. 68:221-231.

Shapiro, S. S., and M. B. Wilk. 1965. An analysis of variance test for normality. Biometrika 52:591-611.

Stadhouders, J. 1960. The hydrolysis of protein during ripening of Dutch cheese. The enzymes and bacteria involved. Neth. Milk Dairy J. 14:83-110.

Ulbricht, T. L. V., and D. A. T. Southgate. 1991. Coronary heart disease: Seven dietary factors. Lancet 338:985-992.

Vinderola, C. G., and J. A. Reinheimer. 1999. Culture media for the enumeration of Bifidobacterium bifidum and Lactobacillus acidophilus in the presence of yoghurt bacteria. Int. Dairy J. 9:497-505.

Williams, C. M. 2000. Dietary fatty acids and human health. Ann. Zootech. 49:165-180. 